\title{
EFFECTS OF GAMMA IRRADIATION ON THE REPRODUCTIVE CAPACITY AND THE LONGEVITY OF PANSTRONGYLUS MEGISTUS (HEMIPTERA: REDUVIIDAE)
}

\author{
PAULO VERÇOSA; PEDRO HENRIQUE DE B. FALCĀO \& ANDRÉ FREIRE FURTADO
}

Centro de Pesquisas Aggeu Magalhães - FIOCRUZ, Caixa Postal 7472, 52020-020 Recife, PE, Brasil

The effects of radiation on the reproductive capacity and the longevity of Panstrongylus megistus were studied.

An indirect correlation between longevity and radiation doses was observed. Males were more affected than females. Longevity of females submitted to $10 \mathrm{~Gy}$ was not different when compared to controls. Some of the irradiated males copulated and in these cases semen was transferred to females, but only few eggs were laid. Fertility was seriously affected in all irradiated groups, decreasing with increasing intensity of dose. The dose of $80 \mathrm{~Gy}$ induced sterility in males and females. Gelatinous spermatophores that were expelled by females irradiated with 20 and $40 \mathrm{~Gy}$, may be a consequence of irradiation that induced modification in the bursa copulatrix $\mathrm{pH}$.

Key words: Panstrongylus megistus - radiation - reproduction - longevity - fertility

Most studies on the effect of ionizing radiation $(x$ or $y)$ on insects have examined damage to the nucleus and chromosomes. Radiation effects on tissues and organs have been carried out only recently, mainly utilizing histopathologic techniques. The hazardous consequences of radiation of the gonads in several species (King, 1957; Dumandji, 1969; Biemont, 1973) has been shown.

Irradiation has also been performed as a means of sterilizing insects. Rahalkar et al. (1975) obtained complete sterilization of Rhynchophorus ferrugineus, when doses higher than 0,0015 Gy were used. Loaharanu et al. (1975), observed that doses of $0,012 \mathrm{~Gy}$ were able to sterilize Aedes aegypty, but such doses were not sufficent to interfere with the ability of the male to copulate.

Males of Rhodnius prolixus were irradiated by Gómez-Núñez et al. (1962), and paired with non irradiated virgin females. These authors observed decrease in the fertility, proportional to doses and age of the insects. Complete sterilization was obtained when doses higher than $400 \mathrm{~Gy}$ were used, nevertheless, longevity and

Received 4 September 1992. Accepted 9 December 1992. the reproductive behaviour of males were affected since they were unable to copulate.

In this study we examined the effects of gamma irradiation on the fecundity, fertility and longevity of males and females of Panstrongylus megistus, the main vector of Chagas disease in Northeast Brazil.

\section{MATERIALS AND METHODS}

Insects - 1200 eggs of $P$. megistus were collected from the insectary of the Centro de Pesquisas Aggeu Magalhães/CPqAM-FIOCRUZ. After hatching, insects were kept in jars and maintained at $28^{\circ} \mathrm{C} \pm 2$ and $\mathrm{R}$. $\mathrm{H}$. of $70-80 \%$.

Feeding - Insects were fed on Gallus sp. from the first larval instar up to adults. Fifth instar larvae were separated into males and females according to Furtado (1977) and groups of ten larvae each were formed. In order to synchronize the moult of insects to be irradiated, only those that have engorged in a single feeding at each stage were selected. Adults were fed once a week.

Experiments - At the imaginal moult, groups of ten insects were put together in Petri dishes, to be irradiated in a ${ }^{60} \mathrm{Co}$ gamma chamber pump, located in the Dept. of Nuclear 
Energy of the Federal University of Pernambuco. Doses of 10, 20,40 and $80 \mathrm{~Gy}$ were used.

After irradiation insects were mated with non irradiated virgin insects. Eight groups of ten pairs were formed. Each pair was put in a glass jar. Controls consisted of ten pairs not submitted to irradiation.

The following observations were recorded daily until the time of death of the irradiated insects: mortality, copulation (confirmed by the expulsion of the spermatophore by the females), laying, and hatching of eggs. After the death of the irradiated male, the female was dissected for a search for spermatozoa in its spermathecae.
Statistical analysis ( $t$ test) were made using $1 \%$ standard deviation between the irradiated groups submitted to the same dose and 5\% among the groups submitted to different doses.

\section{RESULTS}

Doses of $10 G y$ - The non irradiated females that copulated with 10 Gy irradiated males laid eggs that hatched. Those females that did not lay eggs when dissected after the death of the male, showed the spermathecae devoid of spermatozoa. Oocytes were present in their common oviduct (Table I).

All the irradiated females (10 Gy) laid eggs. Hatching was observed except in pair no. 1 that no copulated.

TABLE I

Biological aspects of males and females of Panstrongylus megistus irradiated with $10 \mathrm{~Gy}$

\begin{tabular}{|c|c|c|c|c|c|c|c|c|c|c|c|c|}
\hline \multirow{2}{*}{ Pair } & \multicolumn{2}{|c|}{ Longevity (days) } & \multicolumn{2}{|c|}{ Days of laying } & \multicolumn{2}{|c|}{ Laying } & \multicolumn{2}{|c|}{$\bar{X}$ eggs/day } & \multicolumn{2}{|c|}{ Hatching (\%) } & \multicolumn{2}{|c|}{ Copulation } \\
\hline & $\mathrm{m}$ & $\mathrm{f}$ & $\mathrm{m}$ & $\mathrm{f}$ & $\mathrm{m}$ & f & $\mathrm{m}$ & $\mathrm{f}$ & $\mathrm{m}$ & $\mathrm{f}$ & $\mathrm{m}$ & $\mathbf{f}$ \\
\hline 1 & $101^{a}$ & 136 & 77 & 117 & 127 & 208 & 1,6 & 1,8 & 0 & 0 & 0 & 0 \\
\hline 2 & 103 & 136 & 77 & 103 & 92 & 193 & 1,2 & 1,9 & 16,3 & 73 & 2 & 3 \\
\hline 3 & $101^{a}$ & 146 & 33 & 129 & 57 & 192 & 1,7 & 1,5 & 0 & 80,7 & 0 & 2 \\
\hline 4 & 101 & 138 & 67 & 107 & 207 & 230 & 3,1 & 2,1 & 41,5 & 85,6 & 1 & 1 \\
\hline 5 & $132^{a}$ & 146 & 31 & 107 & 10 & 172 & 0,3 & 1,6 & 0 & 65,1 & 0 & 1 \\
\hline 6 & $136^{a}$ & 138 & 88 & 112 & 27 & 278 & 0,3 & 2,5 & 0 & 78,4 & 0 & 4 \\
\hline 7 & 120 & 158 & 99 & 126 & 159 & 249 & 1,6 & 2 & 66,6 & 78,7 & 2 & 2 \\
\hline 8 & $129^{a}$ & 136 & 31 & 118 & 12 & 313 & 0,4 & 2,6 & 0 & 82,4 & 2 & 2 \\
\hline 9 & 94 & 150 & 70 & 133 & 150 & 306 & 2,1 & 2,3 & 48 & 80 & 1 & 2 \\
\hline 10 & $67^{a}$ & 87 & 35 & 67 & 23 & 84 & 0,6 & 1,3 & 0 & 40,5 & 0 & 2 \\
\hline
\end{tabular}

$\mathrm{m}$ : irradiated males mated with non-irradiated females.

$f:$ irradiated females mated with non-irradiated males.

a: pairs in which females were dissected soon after the death of the irradiated male.

TABLE II

Biological aspects of males and females of Panstrongylus megistus irradiated with $20 \mathrm{~Gy}$

\begin{tabular}{|c|c|c|c|c|c|c|c|c|c|c|c|c|}
\hline \multirow{2}{*}{ Pair } & \multicolumn{2}{|c|}{ Longevity (days) } & \multicolumn{2}{|c|}{ Days of laying } & \multicolumn{2}{|c|}{ Laying } & \multicolumn{2}{|c|}{$\overline{\mathrm{X}}$ eggs/day } & \multicolumn{2}{|c|}{ Hatching (\%) } & \multicolumn{2}{|c|}{ Copulation } \\
\hline & $\mathrm{m}$ & $\mathrm{f}$ & $\mathrm{m}$ & f & $\mathrm{m}$ & f & $\mathrm{m}$ & $\mathrm{f}$ & $\mathrm{m}$ & $\mathrm{f}$ & m & f \\
\hline 1 & $64^{a}$ & 265 & 42 & 131 & 47 & 319 & 1,1 & 2,4 & 0 & 65,2 & 0 & 2 \\
\hline 2 & 129 & 136 & 11 & 92 & 10 & 241 & 0,9 & 2,6 & 0 & 61,8 & 0 & 1 \\
\hline 3 & $101^{a}$ & 77 & 12 & 52 & 4 & 108 & 0,3 & 2,1 & 0 & 49 & 2 & 1 \\
\hline 4 & $63^{a}$ & 165 & 0 & 151 & 0 & 270 & 0 & 1,8 & 0 & 32,5 & 0 & 2 \\
\hline 5 & $109^{d}$ & 104 & 58 & 48 & 24 & 141 & 0,4 & 2,9 & 0 & 54 & 0 & 1 \\
\hline 6 & 174 & 146 & 0 & 126 & 0 & 290 & 0 & 2,3 & 0 & 55,5 & 0 & 4 \\
\hline 7 & 99 & 138 & 78 & 119 & 59 & 225 & 0,7 & 1,9 & 6,7 & 35,5 & 1 & 1 \\
\hline 8 & 132 & 77 & 26 & 32 & 19 & 16 & 0,7 & 0,5 & 21 & 18,7 & 1 & 3 \\
\hline 9 & 139 & 113 & 113 & 74 & 86 & 128 & 0,8 & 1,7 & 23,2 & 49,2 & 6 & 3 \\
\hline 10 & $92^{a}$ & 147 & 42 & 132 & 14 & 251 & 0,3 & 1,9 & 0 & 61,7 & 1 & 2 \\
\hline
\end{tabular}

$\mathrm{m}$ : irradiated males mated with non-irradiated females.

f: irradiated females mated with non-irradiated males.

a: pairs in which females were dissected soon after the death of the irradiated male. 
Longevity and laying were not affected in the irradiated females. Statistical differences were observed only in hatching of eggs laid by these females, when compared to controls (Table VI). In pairs formed by irradiated males and non irradiated females, some differences were also observed with respect to longevity, laying, and hatching at $5 \%$ standard error when compared to controls (Table VI).

When both male and female were irradiated with 10 Gy there is between them one difference on the longevity, laying, and eclosion at a level of $1 \%$ standard deviation (Table VI).

Doses of $20 G y-(a)$ irradiated males + non irradiated females - Although five females from this group had copulated, two of them had spermathecae devoid of spermatozoa and the few eggs laid were infertile. Two other females did not lay eggs (Table II). The reduction in males longevity as well as in the number of the eggs laid by the females, showed a striking difference when compared to controls. (b) irradiated females + non irradiated males - All the females in this group copulated and laid fertile eggs, although a delay in hatching and a decrease in longevity were observed (Table VI). On the other hand, the behaviour of these two groups suggest that the effects of radiation must be attributed more to males than to females.

Longevity of males, the number of eggs laid by the females and hatching were highly

TABLE 111

Biological aspects of males and females of Panstrongylus megistus irradiated with $40 \mathrm{~Gy}$

\begin{tabular}{|c|c|c|c|c|c|c|c|c|c|c|c|c|}
\hline \multirow{2}{*}{ Pair } & \multicolumn{2}{|c|}{ Longevity (days) } & \multicolumn{2}{|c|}{ Days of laying } & \multicolumn{2}{|c|}{ Laying } & \multicolumn{2}{|c|}{$\bar{X}$ eggs/day } & \multicolumn{2}{|c|}{ Hatching (\%) } & \multicolumn{2}{|c|}{ Copulation } \\
\hline & m & $\mathrm{t}$ & $\mathrm{m}$ & $\mathrm{f}$ & $\mathrm{m}$ & t & $\mathrm{ml}$ & $f$ & $\mathrm{~m}$ & f & & $t^{*}$ \\
\hline 1 & $62^{a}$ & 109 & 33 & 78 & 4 & 159 & 0,1 & 2 & 0 & 7,5 & 1 & 3 \\
\hline 2 & $16^{a}$ & 135 & 0 & 1 & 0 & 1 & 0 & 1 & 0 & 0 & 0 & 1 \\
\hline 3 & $50^{a}$ & 133 & 29 & 82 & 4 & 156 & 0,1 & 1,9 & 0 & 0,6 & 0 & 1 \\
\hline 4 & $20^{a}$ & 143 & 0 & 90 & 0 & 161 & 0 & 1,8 & 0 & 9,3 & 0 & 2 \\
\hline 5 & $122^{a}$ & 155 & 101 & 126 & 23 & 127 & 0,1 & 1 & 0 & 39,9 & 1 & 1 \\
\hline 6 & $96^{a}$ & 114 & 61 & 0 & 48 & 0 & 0,8 & 0 & 0 & 0 & 0 & 1 \\
\hline 7 & $40^{a}$ & 84 & 20 & 48 & 2 & 94 & 0,1 & 1,9 & 0 & 5,3 & 0 & 2 \\
\hline 8 & $124^{a}$ & 126 & 74 & 111 & 38 & 137 & 0,5 & 1,2 & 0 & 7,3 & 0 & 1 \\
\hline 9 & 70 & 105 & 52 & 83 & 109 & 102 & 2,1 & 1,2 & 23,8 & 11,8 & 2 & 3 \\
\hline 10 & $35^{a}$ & 74 & 2 & 46 & 5 & 40 & 1,7 & 0.9 & 0 & 15 & 0 & 1 \\
\hline
\end{tabular}

$\mathrm{m}$ : Irradiated males mated with non-irradiated females

f: irradiated females mated with non-irradiated males.

$a$ : pairs in which females were dissected soon after the death of the irradiated male.

TABLL IV

Biological aspects of males and females of Panstrongy/us meg/stus irradjated with $80 \mathrm{~Gy}$

\begin{tabular}{|c|c|c|c|c|c|c|c|c|c|c|c|c|}
\hline \multirow{2}{*}{ Pair } & \multicolumn{2}{|c|}{ Longevity (days) } & \multicolumn{2}{|c|}{ Days of laying } & \multicolumn{2}{|c|}{ Laying } & \multicolumn{2}{|c|}{$\overrightarrow{\mathrm{X}}$ eggs/day } & \multicolumn{2}{|c|}{ Hatching (\%) } & \multicolumn{2}{|c|}{ Copulation } \\
\hline & $\mathrm{m}$ & $\mathrm{f}$ & $\mathrm{m}$ & $\mathrm{t}$ & $\mathrm{m}$ & f & $\mathrm{m}$ & $\mathrm{f}$ & $\mathrm{m}$ & $f^{\circ}$ & $\mathrm{m}$ & $\mathrm{i}^{\circ}$ \\
\hline 1 & $32^{a}$ & $56^{b}$ & 0 & 0 & 0 & 0 & 0 & 0 & 0 & 0 & 0 & 0 \\
\hline 2 & $51^{a}$ & 35 & 1 & 0 & 1 & 0 & 1 & 0 & 0 & 0 & 0 & 0 \\
\hline 3 & $44^{a}$ & 65 & 0 & 1 & 0 & 1 & 0 & 1 & 0 & 0 & 0 & 0 \\
\hline 4 & $45^{a}$ & $56^{b}$ & 0 & 0 & 0 & 0 & 0 & 0 & 0 & 0 & 0 & 2 \\
\hline 5 & $51^{a}$ & 35 & 0 & 6 & 0 & 7 & 0 & 1,1 & 0 & 0 & 0 & I \\
\hline 6 & $18^{a}$ & 66 & 0 & 0 & 0 & 0 & 0 & 0 & 0 & 0 & 0 & 3 \\
\hline 7 & $35^{a}$ & 38 & 6 & 12 & 13 & 18 & 2,1 & 1,5 & 0 & 0 & 0 & 1 \\
\hline 8 & $33^{a}$ & 23 & 0 & 0 & 0 & 0 & 0 & 0 & 0 & 0 & 0 & 0 \\
\hline 9 & $45^{a}$ & 51 & 0 & 25 & 0 & 24 & 0 & 0,9 & 0 & 0 & 0 & 1 \\
\hline 10 & $1^{a}$ & 17 & 0 & 0 & 0 & 0 & 0 & 0 & 0 & 0 & 0 & 0 \\
\hline
\end{tabular}

$\mathrm{m}$ : irradiated males mated with non-irradiated females.

$f$ : irradiated females mated with non-irradiated males.

a: pairs in which females were dissected soon atter the death of the irradiated male.

$b$ : pairs in which irtadiated females were dissected soon atter the death. 
affected when males were treated with the dose of $20 \mathrm{~Gy}$.

Doses of $40 G y-$ (a) irradiated males + non irradiated females - Among the females belonging to this group, three did copulate and two did not lay eggs; nevertheless the eggs of one sole female hatched and only at a percentage of 23.8. At dissection the presence of well developed oocytes in the common oviduct and a complete absence of spermatozoa in their spermathecae was observed. (b) irradiated females + non irradiated males - Expulsion of the spermatophore by all the females belonging to this group, confirmed that copulation occurred. One female did not lay eggs and another one laid only one. Eggs from two females did not hatch (Table III). $50 \%$ of the spermatophores expelled present a gelatinous consistency.

Statistical differences - at a level of $1 \%$ - were observed in laying when a comparison was made between irradiated males and females (Table VI).

Doses of $80 \mathrm{~Gy}$ - (a) irradiated males + non irradiated females - Copulation in this group was not observed. Only two females laid eggs, but they were infertile. Females dissected after the death of the male showed an empty spermathecae, and developed oocytes were retained in their oviducts. Longevity of males was seriously reduced (Table IV). (b) irradiated females + non irradiated males Five females had copulated and four laid eggs, but they did not hatch. One female copulated three times but did not expulsed the third spermatophore; when dissected, spermatozoa were not seen in its spermatechae.

Controls - Data concerning the controls were recorded up to the death of the last irradiated insect, except for longevity, that did not

TABLE V

Controls

\begin{tabular}{rccccccc}
\hline Pair & $\begin{array}{c}\text { Longevity (days) } \\
\text { males }\end{array}$ & $\begin{array}{c}\text { Days of } \\
\text { females }\end{array}$ & $\begin{array}{c}\text { No. of } \\
\text { laging }\end{array}$ & $\begin{array}{c}\bar{X} \text { eggs } / \\
\text { day }\end{array}$ & $\begin{array}{c}\text { Hatching } \\
(\%)\end{array}$ & $\begin{array}{c}\text { Copulation } \\
(\text { No.) }\end{array}$ \\
\hline 1 & 79 & 89 & 76 & 162 & 2,1 & 93.2 & 2 \\
2 & 183 & 154 & 101 & 158 & 1,6 & 81.6 & 3 \\
3 & 174 & 188 & 128 & 154 & 1,2 & 83.4 & 3 \\
4 & 185 & 190 & 165 & 269 & 1,6 & 94.1 & 2 \\
5 & 143 & 172 & 120 & 154 & 1,3 & 90.9 & 4 \\
6 & 166 & 178 & 165 & 261 & 1,6 & 92.7 & 2 \\
7 & 189 & 192 & 151 & 163 & 1,1 & 91.1 & 2 \\
8 & 152 & 181 & 145 & 138 & 0,9 & 82.6 & 3 \\
9 & 192 & 192 & 165 & 264 & 1,6 & 95.5 & 2 \\
10 & 122 & 112 & 100 & 141 & 2,4 & 92.0 & 2 \\
\hline
\end{tabular}

TABLE VI

Statistical analysis (mean and standart deviation) of irradiated males, females and control

\begin{tabular}{|c|c|c|c|c|c|c|c|c|}
\hline \multirow[t]{2}{*}{$\begin{array}{l}\text { Doses } \\
\text { (Gy) }\end{array}$} & \multicolumn{2}{|c|}{$\begin{array}{l}\text { Longevity (days) } \\
(\bar{X} \pm S D)\end{array}$} & \multicolumn{2}{|c|}{$\begin{array}{l}\text { Laying } \\
(\overline{\mathrm{X}} \pm \mathrm{SD})\end{array}$} & \multicolumn{2}{|c|}{$\begin{array}{c}\overline{\mathrm{X}} \text { eggs/day } \\
(\overline{\mathrm{X}} \pm \mathrm{SD})\end{array}$} & \multicolumn{2}{|c|}{$\begin{array}{c}\text { Hatching (\%) } \\
(\overline{\mathrm{X}} \pm \mathrm{SD})\end{array}$} \\
\hline & $\mathrm{m}$ & f & $\mathrm{m}$ & f & $\mathrm{m}$ & $\mathrm{f}$ & $\mathrm{m}$ & $\mathrm{f}$ \\
\hline 10 & $108,4 \pm 21,0$ & $137,1 \pm 19,1$ & $86,4 \pm 70,9$ & $222,5 \pm 68,9$ & $1,3 \pm 0,9$ & $1,9 \pm 0,4$ & $17,2 \pm 25,2$ & $66,4 \pm 26,7$ \\
\hline 20 & $100,2 \pm 27,6$ & $126,8 \pm 32,6$ & $26,3 \pm 28,7$ & $198,9 \pm 96,1$ & $0,5 \pm 0,4$ & $2,0 \pm 0,6$ & $5,1 \pm 9,2$ & $48,3 \pm 14,9$ \\
\hline 40 & $63,5 \pm 39,3$ & $117,8 \pm 41,3$ & $23,3 \pm 34,6$ & $97,7 \pm 63,1$ & $0,5 \pm 0,7$ & $1,3 \pm 0,6$ & $2,4 \pm 7,5$ & $6,1 \pm 5,1$ \\
\hline 80 & $35,5 \pm 15,8$ & $44,2 \pm 17,1$ & $1,4 \pm 4,1$ & $5,0 \pm 8,8$ & $0,3 \pm 0,5$ & $0,5 \pm 0,6$ & - & - \\
\hline $\mathrm{C}$ & \multicolumn{2}{|c|}{$161,6 \pm 35,2$} & \multicolumn{2}{|c|}{$196,4 \pm 54,5$} & $1,5=$ & 50,4 & \multicolumn{2}{|c|}{$89,7 \pm 5,0$} \\
\hline
\end{tabular}

$\mathrm{m}$ : irradiated males mated with non-irradiated females; $\mathrm{f}$ : irradiated females mated with non-irradiated males; $\overline{\mathrm{X}}$ : mean; SD: standard deviation; $\mathrm{C}$ : control. 
varied significantly between males and females. Its was observed a mean of 161,65 days for the longevity of the insects of this group. All pairs copulated and laid eggs. The hatching varied from 81.64 to $95.45 \%$ amongst the pairs (Table V).

\section{DISCUSSION}

Data obtained with irradiation of $P$. megistus, using different doses showed that the longevity of males was affected independent on doses utilized. Males irradiated with $80 \mathrm{~Gy}$ survived only 35,5 days, while longevity of controls was 161,6 days. In contrast females of $P$. megistus seem to be less sensitive to irradiation than males (Fig. 1). Another triatomine, $R$. prolixus, has been shown to have a very high resistance to radiation, requiring a dose of 200 Gy to affect its longevity (GómezNúñez et al., 1962, 1964).

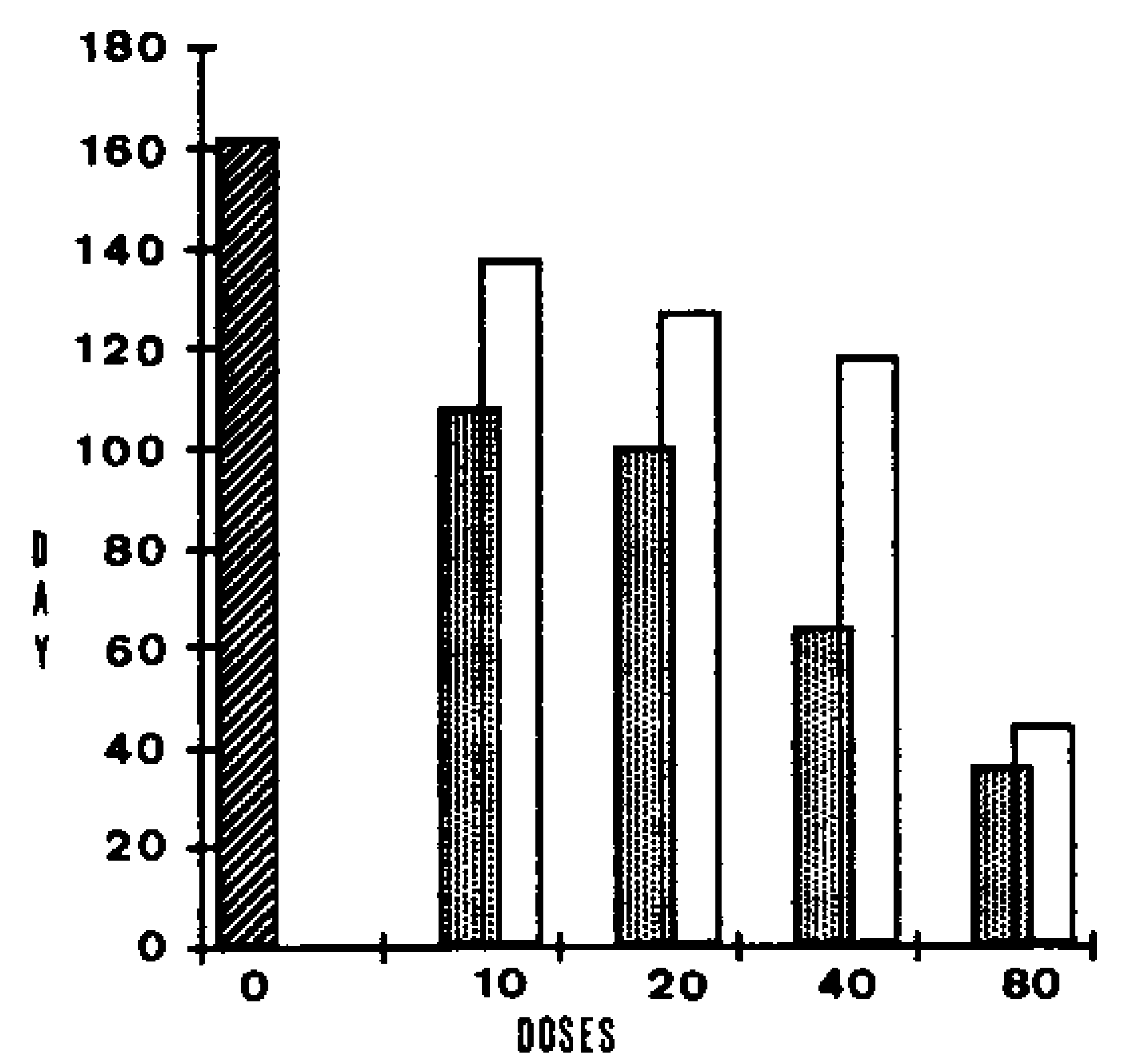

Fig. 1: longevity of males $\square$ and females $\square$ after diferent doses of irradiation. WR controls.

Studies of radiation effects on egg laying have demonstrated that in different insect species there is always an indirect correlation between dose and effect. This was observed by Walder \& Wiendl (1973) in Callosobruchus maculatus and by Rodrigues et al. $(1978,1983$, 1986) in Mahanarva posticata, Sitotroga cerealella and Zabrotes subfasciatus respectively. The same correlation was observed in triatomine by Gómez-Núñez et al. (1962, 1964).

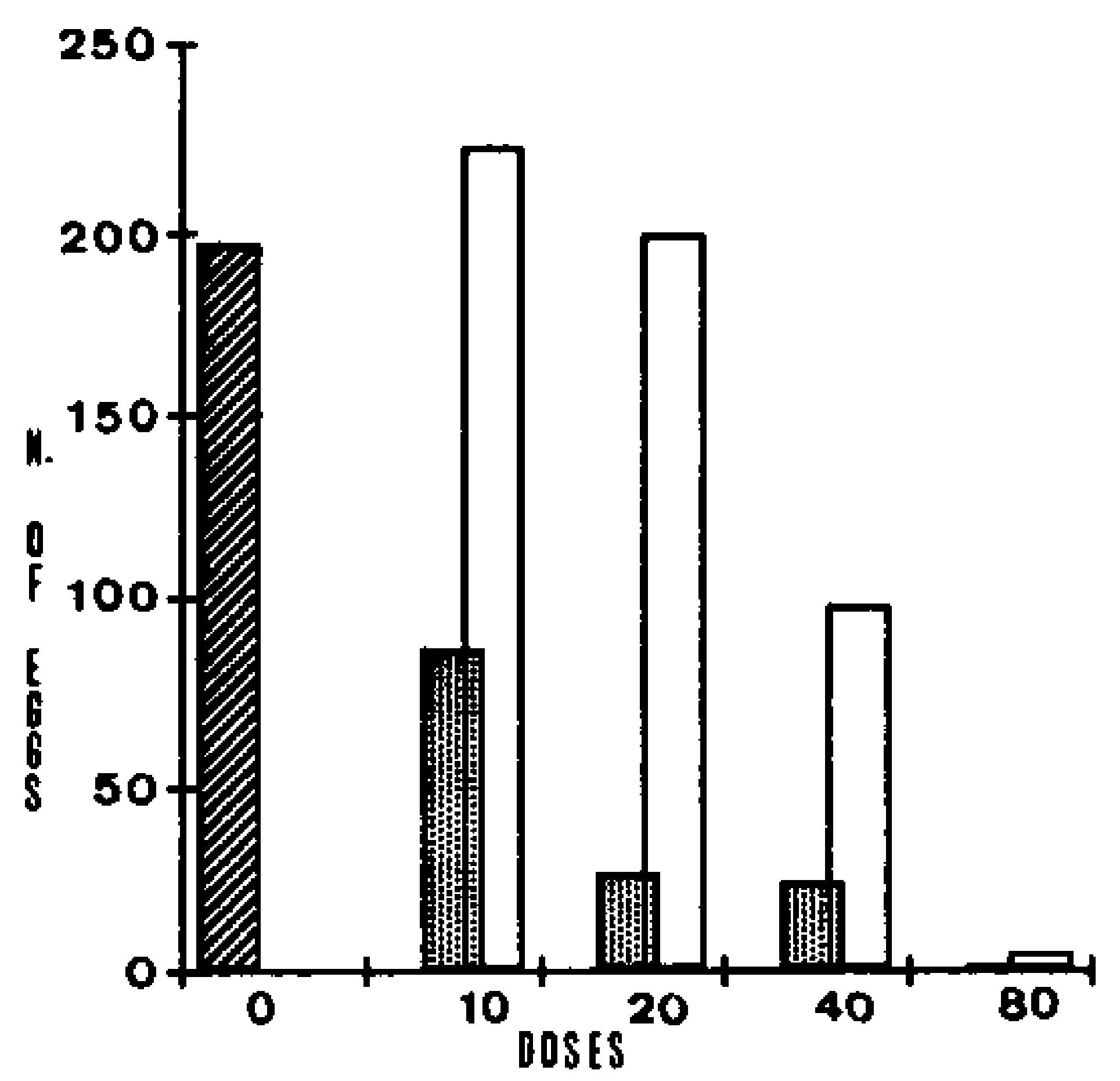

Fig. 2: oviposition of females paired with irradiated males $\gg$ and irradiated females paired with non inadiated males [ $[$ ]. WT controls.

We observed that oviposition was seriously disturbed when females of $P$. megistus were paired with irradiated males (Fig. 2).

Copulation is also affected. The dose of 10 Gy reduced copulation to $40 \%$. This percentage reached $100 \%$ when males were irradiated with $80 \mathrm{~Gy}$. According to Gómez-Núnez et al. $(1962,1964)$ and Loaharanu et al. (1975), the effects of radiation on oviposition are a consequence of the inability of males to copulate. Oviposition in triatomines is stimulated by copulation, (Davey, 1965; Brasileiro, 1982; Brasileiro \& Cunha, 1988). Females are less sensitive to irradiation than males. Laying of eggs by females treated with 10 or 20 Gy was not statistically different than the controls.

A drastic reduction in oviposition was observed when females were irradiated with doses higher than $20 \mathrm{~Gy}$. The number of eggs was reduced to $62.5 \%$ in those insects treated with 40 Gy (Fig. 3). Oviposition was too drasticaly reduced, independent of the occurrence of copulation. when doses of $80 \mathrm{~Gy}$ were applied to insects. It must be taken in consideration that longevity of females was reduced to 44,2 days while in the controls longevity reached 161,6 days. All the eggs laid by the females irradiated with 80 Gy were infertile.

The behaviour of male insects was strongly disturbed by radiation. When males of $A$. aegypti were irradiated with high doses, they became less competitive. Low doses, although 


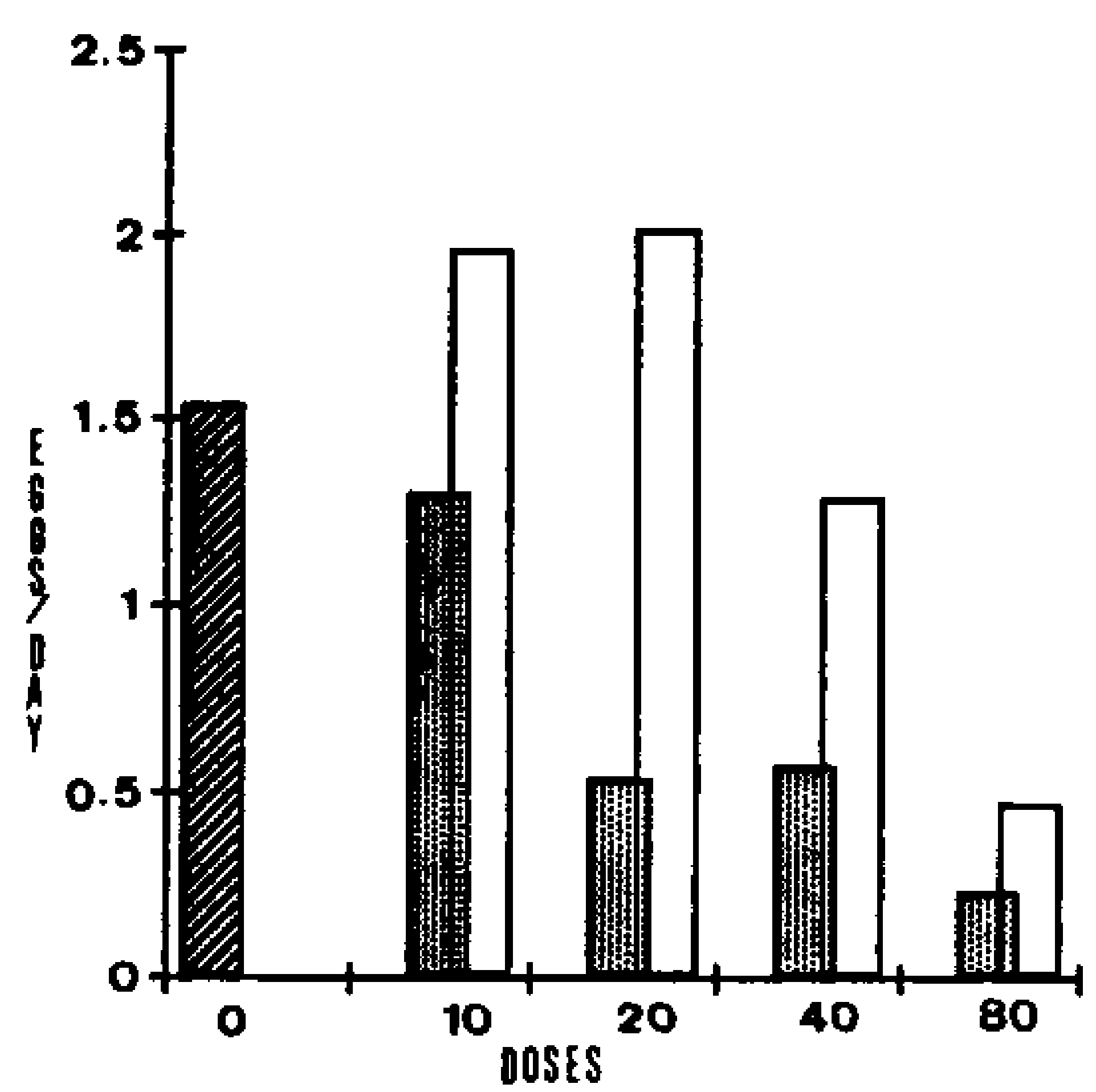

Fig. 3: mean of eggs laid per day by females paired with irradiated males $\$$ and irradiated females paired with non irradiated males $\square$. एव controls

having no effect on copulation, were able to sterilize them (Loaharanu et al., 1975). GomezNuñez et al. $(1962,1964)$ observed that males of $R$. prolixus irradiated with 400 Gy were unable to copulate.

The presence of gelatinous spermatophores, expulsed by the females irradiated with 20 and $40 \mathrm{~Gy}$, might be interpreted as a consequence of radiation on the $\mathrm{pH}$ of the bursa copulatrix (Davey, 1965). The hardening of the spermatophore starts in the genital ductus and finishes when it is expelled by the female. Loaharanu et al. (1975), submitted Spodoptera exigua and $A$. aegypti males to irradiation and observed that hatching of eggs decreased inversely to the dose utilised. Gómez-Núñez et al. (1962) observed that only $3.9 \%$ of the eggs of $R$. prolixus hatched when males were irradiated with $100 \mathrm{~Gy}$ doses, while a value of $85.1 \%$ was obtained for controls. We observed in our experiments that hatching was significantly affected by irradiation of both $P$. megistus males and females. In both groups, the hatching percentage was lower, when compared to controls (Fig. 4). Males of P. megistus are more sensitive to radiation than females. We found a significant inverse correlation between radiation dose and longevity, oviposition, mean of eggs laid per day, and hatching. When doses higher than 20 Gy were used, the longevity and oviposition were affected, and when doses of 80 Gy were employed, the mean of eggs laid per day differred from that of controls.

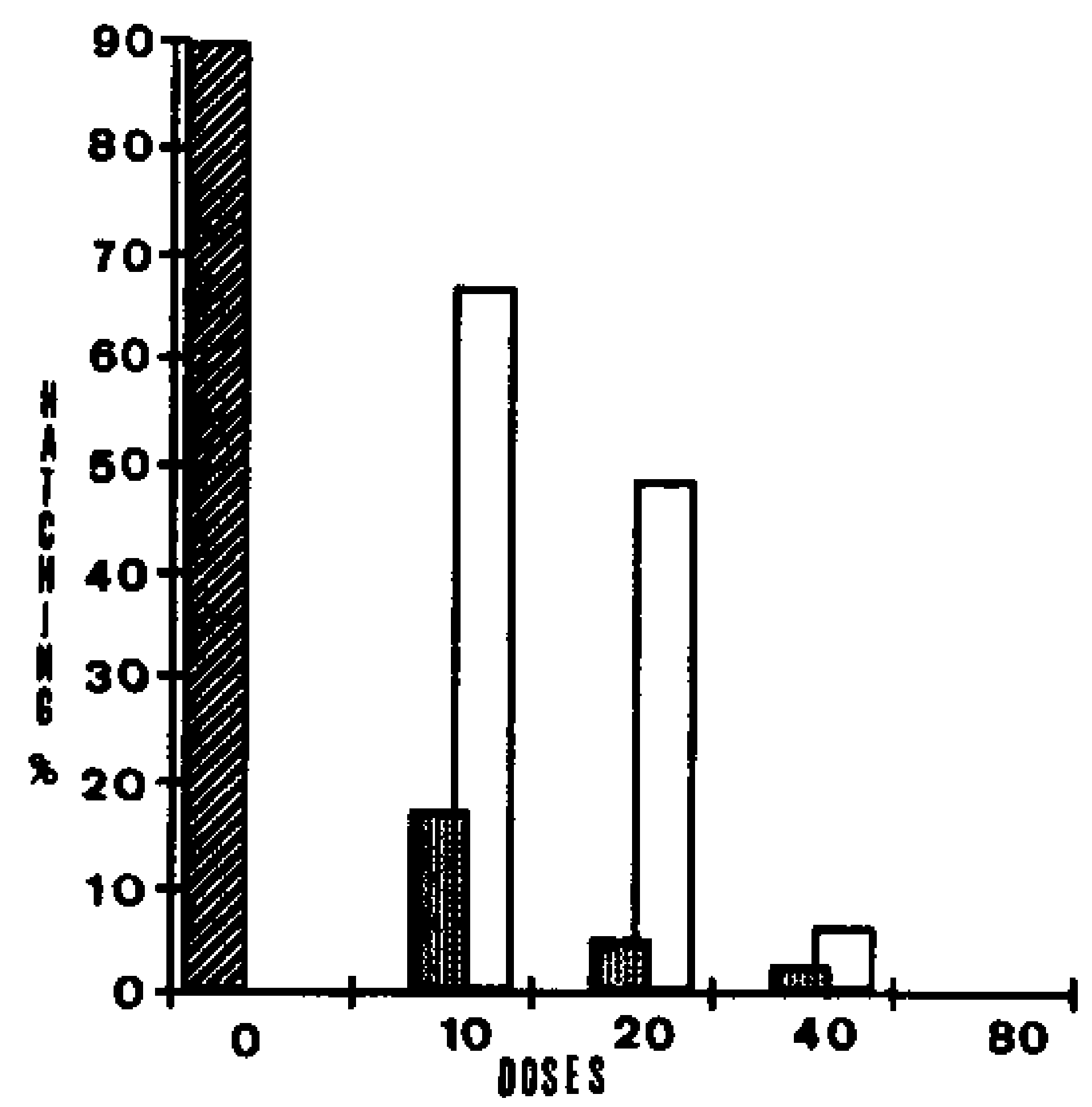

Fig. 4: hatching of eggs from females paired with irradiated males $\mathrm{a}$ and irradiated females paired with non irradiated males $\square$ controls.

\section{ACKNOWLEDGEMENTS}

To the Dept. of Nuclear Energy, Federal University of Pernambuco, for allowing the use of the gamma chamber.

\section{REFERENCES}

BIEMONT, J. C., 1973. Action des rayonnments $X$ sur les ovaires de la bruche du haricot Acanthoscelides obtectus Say (Coléoptère: Bruchidae). C. R. Acad. Sci. Paris, 276: 1471-1474.

BRASILEIRO, V. L. F., 1982. Fecundidade e fertilidade da fêmea de Triatoma brasiliensis (Hemiptera: Reduviidae), I - Influência da cópula e da longevidade. Rev. Bras. Biol., 42: 1-13.

BRASILEIRO, V. L. F. \& CUNHA, C. S., 1988. Maturidade sexual e reprodução em fêmeas de Panstrongylus megistus Burmeister, 1935 (Hemiptera: Reduvidae) em laboratório. Rev. Bras. Entomol., 32: 471-478.

DAVEY, K. G., 1965. The physiology of reproduction in insects. Ann. Soc. Entomol. Québec, 10: 13-25.

DUMANDJI, S., 1969. Actions des radiations gamma sur la fertilité et la longevité d'Acanthocelides obtectus (Coleoptera, Bruchidae). Thèse (Docteur ès Sciences). Université Paris VI, 143 p.

FURTADO, A. F., 1977. Contrôle endocrine des mitoses goniales et du d'éclenchement de la méiose chez la femelle de Panstrongylus megistus (Himiptera: Reduviidae). Thèse Doctorat d'Etat. Université Pierre et Marie Curie, Paris VI, 159 p.

GOMEZ-NÚÑEZ, J. C.; GALLIMORE, J. C.; FERNANDEZ, J. M. \& GROSS, A., 1962. El efecto de las radiaciones ionizantes sobre la biologia y la ecologia de Rhodnius prolixus, vector principal de Schizotrypanum cruzi en Venezuela. Acta Cient. Venezol., 13: 46-52.

GÓML乙-NÚÑEZ, J. C.; GROSS, A. \& MACHADO, C., 1964. Las radiaciones gamma y el comportamiento 
reprodutivo del Rhodnius prolixus macho. Acta Cient. Venezol., 15: 97-104.

KING, R. C., 1957. Oogenesis in adult Drosophila melanogaster, III -- radiation induced ovarian tumors. Growth, 21: 65-83.

LOAHARANU, S.; CHIRA VATANAPONG, S.; SUTANTAWONG, M. \& KAOCHNONG, P., 1975. Mating competitiveness of the radiosterilized male armyworm, Spodoptera exigua, and the male mosquito, Aedes aegypti, in field cages. Sterility Principle for Insect Control - IAEA, 186: 317-323.

RAHALKAR, G. W.; HARWALKAR, M. R. \& RANANAVARE, H. O., 1975. Laboratory studies on sterilization on the male red palm weevil, Rhynchophorus fernugineus Oliv. Sterility Principle for Insect Control-IAEA, /86: 12.

RODRIGUES, Z. A.; REGO, A. M.; OLIVEIRA, M. L.; MENDONÇA, C. \& FERREIRA, D., 1978. Efeitos da radiação gama em Mahanarva posticata (Homoptera; Cercopidae) nas condições biológicas do Nordeste Brasileiro. Rev. Nord. Biol., l: 8388.

RODRIGUES, Z. A.; REGO, A. M.; OLIVEIRA, M. L. \& FERREIRA, D., 1983. Efeitos da radiação gama cobalto $60 \mathrm{em}$ ovos e adultos de Sitotroga cerealella (Leptoptera: Gelechiidae) em laboratório. Ciên. Cult., 35: 1657-1661.

RODRIGUES, Z. A.; REGO, A. M. \& OLIVEIRA, M. L., 1986. Esterilização e efeitos letais da radiação gama cobalto em ovos e adultos de Zabrotes subfasciatus (Coleoptera: Bruchidae). Ciên. Cult., 38: $1597-1600$.

WALDER, J. M. M. \& WIENDL, F. M., 1973. Influência da radiação gama na oviposição e longevidade de Callosobruchus maculatus Fabr., 1972 (Coleoptera: Bruchidae). An. Soc. Bras. Entomol., 2: 102-108. 